\title{
Effects of Cooling on the Reproductive Performance of Gilts
}

\section{*1OYEDEJI, JO; IMAGBENIKARO GO}

\author{
Department of Animal Science and Animal Technology, \\ Faculty of Agriculture and Agricultural Technology, \\ Benson Idahosa University, Ugbor, Benin City \\ Email: Gimagbenikaro@biu.edu.ng
}

\begin{abstract}
The study examined the effect of cooling on the reproductive performance of gilts using 27 Large White Experimental Gilts on a Completely Randomized Design (CRD) with 3 systems of cooling, namely Wallow Cooling (WC), Sprinkler Cooling (SC) and Zero Cooling (ZC). Gilts were weighed at the commencement of the experiment and thereafter fed ad libitum from service to farrowing. Feed intake till farrow, feed cost, gilt weight at farrow, date of farrow, litter size and weight were recorded. The feed/piglet weight, feed intake/litter, feed cost/litter and birth weight/piglet were derived. The results showed that feed intake per litter and feed per piglet weight were highest for gilts placed on $\mathrm{WC}(\mathrm{P}<0.05)$, followed by SC and least for sow placed on ZC; gilt weight before farrow was highest for sow placed on SC $(69.78 \pm 0.92)$, followed by ZC $(69.33 \pm 0.94)$ and least for gilts placed on WC (67.33 \pm 0.87$)$; litter sizes of gilts placed under the WC and SC systems were similar (5.6 \pm 0.41$)$ while that under the ZC system was comparatively smaller $(5.4 \pm 0.40)$; while the date of farrow was lowest in the ZC system (113.8 \pm 0.32$)$ followed by SC $(114.0 \pm 0.33)$ and highest under the WC (114.1 \pm 0.33$)$. However, the feed intake per litter, feed per piglet weight, litter sizes of gilts, birth weight per piglet of gilts and the average date of farrow among gilts placed on WC, SC and ZC were not statistically different at 5\% level of significance. Though, there is no significant difference in the performance among gilts placed on $\mathrm{WC}, \mathrm{SC}$ and $\mathrm{ZC}$, temperature regulation through provision of efficient cooling system in piggery would help to increase litter size, improve feed intake per litter and reduce the average cost of feeding gilt per day in maximizing reproductive performances in pigs. (C) JASEM
\end{abstract}

\section{http://dx.doi.org/10.4314/jasem.v20i2.17}

Keywords: Cooling, gilts, service, farrow, piggery, litter size, piglet and birth weight.

\section{Introduction}

Pork is the most popular meat produced and consumed in the world today as about $44 \%$ of world meat protein consumption is derived from pork and pork products while beef constitutes $24 \%$, chicken $29 \%$ and turkey 2\% (FAO, 2003; Holmes, 2005; Ajala et al, 2007; FAO, 2010; Nwosu, 2011; Adebambo, 2012). Nevertheless, tropical weather condition constitutes a great challenge to pig production. It has been reported that livestock exposure to harsh weather conditions affect energy transfer between the animal and its surrounding and this can deleteriously affect performance (Rensis and Scaramuzzu, 2003; Bernabucci et al, 2010 and Nwosu and Ogbu, 2011). The reproductive performance of pigs, for instance, is not only influenced by nutrition but also by environmental conditions (Fagundes et al, 2009 and Nwosu and Ogbu, 2011). The deleterious effects of high ambient temperature on reproductive performance have been widely reported in farm animal species (Zurek et al, 1995; Collins et al, 2001; Gates et al, 2001; Renaudeau et al, 2007 and Stansbury et al, 2007). This is so because pig's body temperature can vary with the temperature of its surroundings and a steady body temperature is important for a proper growth rate. Since pigs lack sweat glands, evaporation takes place through the mouth, besides others, as exemplified by panting during hot weather. But if the animal is unable to get rid of excess heat in one way or another, it will reduce its body temperature by producing less heat. If cold, pigs prevent further cooling by generating more heat through shivering. This shivering exercise will use up the pigs' energy and subsequently result in growth rate reduction. In order to cope with the adverse effects of high ambient temperature on the productivity of livestock, experts have advocated environmental modification and crossbreeding using tropically adapted breeds (Rowlinson, 2008; and Nwosu and Ogbu, 2011). While it is generally agreed that cooling is necessary for pig production, the search for the most effective method of cooling is ongoing. This study, therefore, 
examined the effect of different cooling methods on the reproductive performance of gilts.

\section{MATERIALS AND METHODS}

The feeding trial was conducted at Omeko Farms at Ahor village near Benin City, Edo State in Nigeria for a period of 6 months spanning August, 2013 through January, 2014 using 27 Large White Experimental Gilts of similar age and weight mated at their second oestrus. The pigs were dewormed and allowed an adaptation period of 7 days before the experiment began and fed ad libitum from service to farrowing and were randomly distributed across treatments. Drinking water was also presented to satisfaction throughout the experimental period. Initial weights of gilts were recorded

The ambient temperatures at the period of study ranged from $18^{\circ} \mathrm{C}-24^{\circ} \mathrm{C}$ minimum to $30^{\circ} \mathrm{C}-36^{\circ} \mathrm{C}$ maximum while experimental pen temperatures ranged from $24.2^{\circ} \mathrm{C}$ to $35.9^{\circ} \mathrm{C}$ during the day. The 3 systems of cooling were Wallow Cooling (WC), Sprinkler Cooling (SC) and Zero Cooling (ZC) respectively.

Table 1: Percentage Composition of Experimental Diet

\begin{tabular}{lc}
\hline & Percentage Composition \\
\hline Ingredient & Diet \\
Cassava & 30.00 \\
Groundnut cake & 10.00 \\
Wheat bran & 38.00 \\
Palm kernel cake & 15.00 \\
Palm oil & 2.65 \\
Limestone & 3.65 \\
Salt & 0.50 \\
Premix* & 0.20 \\
Total & 100.00 \\
& Proximate Composition (Analysed) \\
Crude Protein (\%) & 14.56 \\
Fat $\%$ ) & 4.30 \\
Fibre (\%) & 5.30 \\
Ash (\%) & 15.80 \\
Moisture (\%) & 8.50 \\
Energy (DE,Kcal/kg) & 2688.36 \\
\hline Biomix: Vit A 10,00000
\end{tabular}

*Biomix: Vit.A 10,000,000 I.U, Vit. D3 2,000,000 I.U. Vit. E 10,000mg,Vit.K3 1,000mg,Vit.B1 1500mg,Vit.B2 4500mg,Vit.B6 3000mg,Vit.B12 15mg,Naicin 15000mg, Pantothenic acid 4500mg

The gilts were housed in 27 standard pens with 9 of the pens installed with Sprinklers (shower) for cooling (SC), another 9 pens had inbuilt wallow (WC) while the last 9 did not have any cooling system installed (ZC). Each gilt had a pen space of $4 \times 3$ metres concrete floor throughout the period of the study. Hygienic environment was maintained by regular pen and wallow cleaning at least twice daily.. The ambient temperature of the study pens were taken using a thermometer. Data on feed intake were recorded on a weekly basis while the gilts weights at the end of gestation before farrowing were recorded. At farrowing, the number of piglets was recorded. Litter weight was also taken while litters were inspected for any still birth or deformity. Proximate composition of the experimental diet was determined using the method of AOAC (1995). Data obtained were subjected to Analysis of Variance (ANOVA) for Completely Randomized Design, CRD using the computer package Genstat to test for levels of significance

\section{RESULTS AND DISCUSSION}

Table 2: Estimates of Performance of Gilts

\begin{tabular}{lccc}
\hline \multicolumn{1}{c}{ Parameters } & Wallow Cooling & Sprinkler Cooling & Zero Cooling \\
\hline Feed intake till farrow (kg) & $258.2 \pm 4.97$ & $255.0 \pm 4.95$ & $254.8 \pm 4.92$ \\
Feed intake/litter (kg) & $46.44 \pm 0.49$ & $45.86 \pm 0.51$ & $46.84 \pm 0.49$ \\
Feed/piglet weight (kg) & $260.81 \pm 7.11$ & $250.0 \pm 7.92$ & $247.4 \pm 8.11$ \\
Feed cost (N) & $2669 \pm 112.0$ & $2864 \pm 109.7$ & $2671 \pm 109.2$ \\
Feed cost/litter (N) & $14325 \pm 550.90$ & $14147 \pm 554.92$ & $12562 \pm 549.88$ \\
\hline
\end{tabular}


The results of cooling level on the feeding parameters are presented in Table 2 . The results showed that feed intake per litter was highest for sow placed on Wallow Cooling (46.44kg), followed by Sprinkler Cooling $(45.86 \mathrm{~kg})$ and least for sow placed on Zero Cooling $(46.84 \mathrm{~kg})$ with greater variability in the feed intake per litter for sprinkler level. However, the average feed intake between Wallow Cooling (WC), Sprinkler Cooling (SC) and Zero Cooling (ZC) applied to sows was not statistically different at $5 \%$ level of significance. This suggests that gilts on wallow cooling consume more feed on average than the other levels of cooling systems. The same pattern was observed for feed per piglet weight except that the variability was highest for gilts placed on zero cooling. This indicates a greater weight gain per unit feed intake by gilts on wallow cooling system compared with the other levels of cooling. The result suggests that there was better nutrient utilization of the feed consumed for body maintenance and growth by gilts placed on wallow cooling system than gilts on other systems of cooling. This better performance of sows placed on the Wallow Cooling (WC) system may not be unconnected with the easy and unrestricted access of the gestating gilts to cooling on a continuous basis provided by the Wallow Cooling (WC) system as against the intermittent cooling provided by the Sprinkler Cooling (SC) system and absence of cooling in the Zero Cooling (ZC) system. This is in agreement with the positions of Christon (1988), Serres (1992) and Olomu and Oboh (1995) that gilts show improved feed intake under conditions of continuous water cooling. The results also showed that the feed intake till farrow was highest for gilts placed on wallow cooling system $(258.20 \mathrm{Kg})$ but least for gilts on zero cooling $(254.80 \mathrm{Kg})$ with the highest variation for gilts on wallow system. On the feed cost, the average cost of feeding gilt per day was highest for gilts placed on sprinkler cooling ( $\$ 2864$ ), followed by gilts on zero cooling (\$2671) and least for gilts placed on wallow cooling (\$2669). This pattern was different with respect to feed cost per litter. The average feed cost per litter and variability for gilts placed on wallow cooling was highest ( $\$ 14325 \pm 550.90)$ and least for gilts on zero cooling ( $\$ 12562 \pm$ 549.88). The poor performances of gestating gilts (especially in terms of litter size) under the Zero Cooling (ZC) system agrees with researches that reported the deleterious effects of high ambient temperature on performance in farm animal species (Gates et al, 2001; Renaudeau et al, 2007; Zumbach et al, 2008).

Table 3: Estimates of Reproductive Performance of Gilts

\begin{tabular}{lccc}
\hline \multicolumn{1}{c}{ Parameters } & Wallow Cooling & Sprinkler Cooling & Zero Cooling \\
\hline Gilt weight before farrow $(\mathrm{kg})$ & $67.33 \pm 0.87$ & $69.78 \pm 0.92$ & $69.33 \pm 0.94$ \\
Date of farrow & $114.1 \pm 0.33$ & $114.0 \pm 0.33$ & $113.8 \pm 0.32$ \\
Litter size(kg) & $5.6 \pm 0.41$ & $5.6 \pm 0.41$ & $5.4 \pm 0.40$ \\
Birth weight/piglet $(\mathrm{kg})$ & $0.99 \pm 0.02$ & $1.02 \pm 0.03$ & $1.03 \pm 0.03$ \\
Litter weight $(\mathrm{kg})$ & $5.50 \pm 0.11$ & $5.67 \pm 0.12$ & $5.71 \pm 0.12$ \\
\hline
\end{tabular}

The results of cooling level on the reproductive parameters are presented in Table 3. The results showed that gilt weight before farrow was highest for sow placed on Sprinkler Cooling (SC) $(69.78 \pm 0.92)$, followed by Zero Cooling $(69.33 \pm 0.94)$ and least for sow placed on Wallow Cooling $(67.33 \pm 0.87)$ with greater variability in the gilt weight before farrow for wallow level. However, the average gilt weight before farrow between Wallow Cooling (WC), Sprinkler Cooling (SC) and Zero Cooling (ZC) was not statistically different at $5 \%$ level of significance. This suggests that gilts on sprinkler cooling added more weight on average than the other cooling systems. The date of farrow was lowest in the zero cooling system $(113.8 \pm 0.32)$ followed by Sprinkler cooling (114.0 \pm $0.33)$ and highest under the wallow cooling (114.1 \pm $0.33)$.However, the average date of farrow between Wallow Cooling (WC), Sprinkler Cooling (SC) and
Zero Cooling (ZC) was not statistically different at 5\% level of significance. This earlier date of farrow of gilts placed on the zero cooling (WC) system is not clearly understood.

The litter sizes of gilts placed under the wallow and sprinkler cooling systems were similar $(5.6 \pm 0.41)$ while that under the zero cooling system was comparatively smaller $(5.4 \pm 0.40)$. However, the average litter size between Wallow Cooling (WC), Sprinkler Cooling (SC) and Zero Cooling (ZC) was not statistically different at 5\% level of significance. The result showed that the birth weight per piglet of gilts under wallow cooling, sprinkler cooling and zero cooling systems were $0.99 \pm 0.02,1.02 \pm 0.03$ and 1.03 \pm 0.03 respectively and the average birth weight per litter was not statistically different at $5 \%$ level of significance under the various cooling systems. 
The litter weight under wallow cooling, sprinkler cooling and zero cooling systems are $5.50 \pm 0.11 ; 5.67$ \pm 0.12 and $5.71 \pm 0.12$ respectively and the litter weight was not statistically different at $5 \%$ level of significance under the three cooling systems. The zero cooling system though with a comparatively smaller litter size of $(5.4 \pm 0.40)$ had a better litter weight (5.71 $\pm 0.12)$ than wallow and sprinkler cooling systems with $5.50 \pm 0.11$ and $5.67 \pm 0.12$ respectively.

Conclusion: The study examined the effect of cooling on the performance of gilts. The results showed that although, there is no significant difference in the performance among gilts placed on $\mathrm{WC}, \mathrm{SC}$ and $\mathrm{ZC}$, but temperature regulation through provision of efficient cooling system in piggery would help to increase litter size, improve feed intake per litter and reduce the average cost of feeding gilt per day in maximizing performances in pigs.

\section{REFERENCES}

Adebambo, O. (2012). Evaluation of genetic potential of the Nigeria Indigenous Pig. $2^{\text {nd }}$ World Conference on Genetics applied to Livestock, Maldrid, Spain.

Ajala, M. K.; Adesehinwa, A. O. K. and A. K.Mohammed (2007).Characteristics of smallholder pig production in Southern Kaduna Area of Kaduna State, Nigeria. AmericanEurasian J. Agric. and Environmental Science 2 (2): 182-188.

AOAC (1995). Official Methods of Analysis (16th Ed.). Association of Official Analytical Chemists, Arlington, VA.

Christon, R. (1988). The effect of tropical ambient temperature on growth and metabolism in pigs. Journal of Animal Science. 66:3112-3123.

Collins, A., van Milgen, J., Dubois, S. and J. Noblet (2001). Effect of high temperature on feeding behavior and heat production in group-housed young pigs. British Journal of Nutrition, 86:63-65.

F.A.O. (2010). Food and Agriculture Organization; Food and Agriculture Organization Yearbook. Pp. 50-54

F.A.O. (2003). Food and Agriculture Organization; Food and Agriculture Organization Yearbook. Pp. 24-28

Fagundes, A. C., Stone, B. A. and T. A. Torrey (2009).Influence of environmental temperature, dietary energy level and sex on performance and carcass characteristics of pigs. In Brazilian Journal of Veterinary Research and Animal Science. 46(1):13-85.

Gates, R. S. (2001). The effect of high temperature on reproductive performance in farm animal species. Journal of Animal and Plant Science 24(1):2014 pg 43-44.

Gates, R. S., Zulovich, J.M., Turner,L., Wurm, J., and M. F. G. Johnson (2001).Gonadotrophin Secretion: the LH response to realigmentation and a nocturnal increment in LH secretion of feedrestricted prepubertal gilts. Journal of Reproductive Fertility 98:293-300.

Genstat for Windows (2000).Release 4.2.5th ed. VSN International Ltd., Oxford, U.K.

Holmes, R. N. (2005). The effect of Protein Metabolism of Pigs growing at a high ambient temperature. Journal of Animal Production $12: 107-110$

NIFOR: Nigeria Institute of Oil Palm Research Meteorological Centre weather report of (2013 and January 2014) Benin City, Edo State, Nigeria.

Nwosu, C. C. and C. C. Ogbu (2011). Characteristics of smallholder pig production in Southern Kaduna Area of Kaduna State, Nigeria. AmericanEurasian J. Agric. and Environmental Science 2 (2) 182-188, 2007

Nwosu, C.C. and C.C. Ogbu (2011).Climate change and livestock production in Nigeria. Agro-Science J. Tropical Agriculture, Food, Environment and Extension 10(1):41-58.

Olomu, J. M. and S. O. Oboh (1995).Pig Production in Nigeria - Principles and Techniques ( $\left.1^{\text {st }} \mathrm{Ed}\right)$ Jachem Company Nigeria pp. 4, 71-83

Renaudeau, D. (2005). Effects of short-term exposure to high ambient temperature and relative humidity on thermoregulatory responses of European (Large White) and Caribbean (Creole) restrictively fed growing pigs. Anim. Res.54:8193.

Rensis, D. F. and R. J. Scaramuzzi (2003).Heat stress and seasonal effects on reproduction in the dairy cow-a review. Theriogenology 60:1139reproductive axis: Perspectives and mechanisms. Biology of Reproduction 60:216-222. 
Rowlinson, P. (2008). Adapting livestock production systems to climate change-temperate zones. Livestock and Global Change Conference Proceeding,May,2008,Tunisia

Serres, H. (1992). Influence of tropical climate on pig behavior. In: H. Serres lactating sows during heat stress: effects of water drip, snout coolers, floor type and a high energy-density diet. Journal of Animal Science 66:885-889
Stansbury, W. F., Mcglone, J. J. and L. F. Tribble (2007). Effects of season, floor type, air temperature and snout coolers on sow and litter performance. Journal of Animal Science 65:15071513.

Zurek, E., Foxcroft, G. R. and J. J. Kennelly (1995). Metabolic status and mechanisms mediating nutritional effects on embryonic survival in pigs .J. Reprod. Fertil. Suppl. 52:47-61. 